\title{
COMMUNITY MOVEMENT IN WASTE MANAGEMENT (Case in Cikapundung River Basin in Bandung City)
}

\author{
Bintarsih Sekarningrum (bintarsihcat@yahoo.com) \\ Desi Yunita (dey.radsya@gmail.com)
}

\author{
Program Studi Sosiologi FISIP UNPAD
}

\begin{abstract}
There is a connection between the behaviour of throwing waste into the river with the community perspective about river. The behaviour of people throwing waste into the river assosiated with the lack of availability of facilities dispose of waste in the area and looked at the river as an object or place that is easiest to throw garbage into the river. Related to these problems, this research describes the community who doing the social movement in waste management a long the river, as well as analyzing patterns of community organizing in waste management.The approach used is a qualitative method of data collection techniques consisted of observation, interviews and focus group discussions. Research shows that the government has made efforts through the program "Clean Cikapundung River", and waste management efforts, sediment transport and manufacture kirmir on a riverbank to prevent abrasion. However Cikapundung still dirty and full of trash. To overcome these problems, there are many communities who awakened and stirred to make an effort in order Cikapundung no longer become dumping grounds. The movement to strive for existence of the river can be used again as an important source of livelihood for the people. Community was formed to instill public awareness of the environment, especially rivers, in the form of an appeal and a call to people not to throw garbage into the river and do the cleaning and arrangement along the river so that the river Cikapundung clean and free of trash based on solidarity and mutual assistance. The social movements showed public awareness to make changes to their environment, especially the problem of waste in the river.
\end{abstract}

Key words : Social movement, community, waste

\section{PENDAHULUAN}

Hasil penelitian tentang perilaku dan persepsi masyarakat dalam membuang sampah di bantaran Sungai Cikapundung (Sekarningrum et al, 2012), menunjukkan bahwa terdapat hubungan antara kebiasaan perilaku membuang sampah ke sungai dengan cara pandang atau persepsi masyarakat terhadap sungai. Perilaku masyarakat membuang 
sampah di sungai terkait dengan kurang tersedianya fasilitas membuang sampah di wilayah tersebut dan sungai dianggap sebagai tempat yang paling mudah untuk membuang sampah rumah tangga.

Pandangan masyarakat terhadap sungai masih sebatas objek atau tempat yang termudah untuk membuang sampah. Cara pandang ini dimaknai bahwa perilaku membuang sampah di sungai berhubungan dengan cara pandang masyarakat memaknai keberadaan sungai bukan sebagai bagian hidup yang berkorelasi dengan keberlanjutan hidup ke depannya. Masyarakat lebih berorientasi untuk hidup saat ini, walaupun secara sadar masyarakat mengetahui dampak dari perilaku membuang sampah ke sungai berdampak negatif bagi masyarakat.

Upaya penanggulangan sampah sudah dilakukan baik oleh pihak pemerintah maupun komunitas yang setempat. Pemerintah melakukan gerakan melalui "Cikapundung Bersih" dan pembuatan kirmir di pinggiran sungai untuk mencegah abrasi. Sementara itu komunitas melakukan upaya agar sungai Cikapundung tidak lagi menjadi tempat pembuangan sampah. Gerakan tersebut mengupayakan agar sungai dapat difungsikan keberadaannya dan diharapkan dapat bernilai ekonomis bagi masyarakat setempat. Komunitas yang terbangun tersebut dibentuk oleh warga setempatyang peduli akan lingkungan Sungai Cikapundung.

Komunitas yang terbangun tersebut menunjukkan masih ada masyarakat yang peduli untuk melakukan gerakan sosial untuk melakukan pengelolaan sampah di bantaran Sungai Cikapundung. Oleh karena itu perlu untuk melakukan penelitian tentang :(1) bagaimana komunitas-komunitas yang terbangun melakukan gerakan sosial dalam upaya penyadaran dan pengeloaan sampah di bantaran Sungai Cikapundung, (2) bagaimana pola pengorganisasian masyarakat dalam pengelolaan sampah di sepanjang bantaran sungai Cikapundung Kota Bandung?

\section{METODE PENELITIAN}

Metode yang digunakan dalam penelitian ini adalah metode penelitian kualitatif. Data primer diperoleh dari wawancara mendalam, pengamatan dan diskusi terfokus (FGD) pada komunitas di lima kelurahan. Sedangkan data sekunder dikumpulkan dari hasil olahan data orang lain baik berupa dokumen, publikasi dan sebagainya. Untuk data primer, informasi yang dikumpulkan berkaitan dengan komunitas yang melakukan gerakan sosial di Cikapundung, latar belakang komunitas, 
tujuan dan sasaran komunitas, bentuk gerakan yang sudah dilakukan, pola pengorganisasian gerakan komunitas, hasil dan hambatan gerakan sosial komunitas. Sedangkan informasi yang digali melalui wawancara yaitu situasi dan kondisi komunitas dalam melakukan gerakan sosial serta situasi dan kondisi masyarakat di bantaran sungai Cikapundung. Informan penelitian terdiri dari tokoh gerakan komunitas, pengurus komunitas, dan masyarakat yang menjadi anggota komunitas. Data dianalisa dengan analisa deskriptif yaitu mengorganisasikan dan mengurutkan data ke dalam pola, kategori dan satuan uraian dasar, sehingga dapat ditemukan dan disimpulkan.

\section{HASIL DAN PEMBAHASAN}

\section{Gambaran Umum Wilayah Penelitian}

Kelurahan Cipaganti, memiliki jumlah penduduk sebesar 10.383 jiwa, mayoritas penduduknya memiliki tingkat pendidikan yang rendah. Kelurahan Cipaganti merupakan salah satu wilayah wisata belanja dan "Sentra Penjualan Jeans" terutama di sekitar jalan Cihampelas, dan merupakan salah satu dari lima sentra unggulan yang ada di Kota Bandung. Namun wilayah tersebut kurang memiliki infrastruktur dan ruang publik yang memadai bagi masyarakat. Kondisi perumahannya termasuk dalam wilayah yang padat, sehingga terdapat wilayah pemukiman yang kumuh terutama di sepanjang Sungai Cikapundung. Penduduk yang berada di kawasan tersebut merupakan penduduk miskin yang memiliki tingkat pendidikan formal yang rendah (Sumber : Profil dan Tipologi Kelurahan Cipaganti, tahun 2013).

Kelurahan Lebak Siliwangi, jumlah penduduk sebesar 4.239 jiwa, mayoritas adalah penduduk usia sekolah. Wilayah ini memiliki wisata Kebun Binatang yang secara ekonomi telah memberikan keuntungan bagi masyarakat sekitar untuk berjualan atau jasa perdagangan lainnya, namun di lain pihak menimbulkan permasalahan terkait dengan kemacetan dan banyaknya sampah di wilayah tersebut. Sebagian besar penduduk memiliki bangunan rumah yang permanen (490 rumah), namun sebagian lagi terdiri dari bangunan semi permanen (210 rumah) dan tidak permanen (18 buah) yang umumnya kurang memiliki sanitasi yang baik (Profil dan Tipologi Kelurahan Lebak Siliwangi, tahun 2013).

Kelurahan Tamansari, jumlah penduduknya sebanyak 24.897 jiwa yang mayoritas penduduknya (5.266 orang) adalah tamatan SD. Umumnya penduduk yang bermukim adalah penduduk pendatang dari pesisir pantai utara dan selatan (Cirebon, Tasikmalaya, Pangandaran, 
Ciamis dan Tegal) yang datang ke Kota Bandung untuk mengadu nasib bersama kerabat-kerabatnya. Mereka memiliki pendapatan yang rendah, sehingga bermukim di tempat yang kumuh di daerah bantaran sungai Cikapundung. Namun ada pula penduduk lama yang tinggal di daerah bantaran sungai yang bermukim sudah lebih dari 20 tahun (http://www.pdfe8dc.org). Kondisi pemukiman sangat padat dan sebagian besar bangunan melatarbelakangi sungai dengan status tanah sebagian besar adalah milik negara. Dengan tata letak bangunan tersebut, maka pembuangan sampah atau limbah rumah tangga dibuang ke sungai, sehingga terjadi pencemaran air sungai Cikapundung(Universitas Komputer Indonesia, 2012).

Kelurahan Braga,jumlah penduduk sebanyak 6.259 jiwa dengan keadaan penduduk yang heterogen baik dari segi adat istiadat, taraf kehidupan, status sosial maupun taraf pendidikan, sehingga sebagian kelompok warga yang satu dengan kelompok warga yang lain tidak saling mengenal (Profil dan Tipologi Kelurahan Braga, 2013). Kondisi pemukiman di Kelurahan Braga (RW 04), menunjukkan banyak pemukiman liar dan kumuh yang menempati lahan di bantaran Sungai Cikapundung. Kondisi bangunan umumnya tidak memenuhi prasyarat teknis dan kesehatan serta bangunan yang tidak layak huni, karena tidak ada sirkulasi udara yang baik, kepadatan bangunan yang tinggi, rawan banjir jika turun hujan, serta kurangnya sarana dan prasarana (Universitas Komputer Indonesia, 2012).

Kelurahan Babakan Ciamis, jumlah penduduk sebanyak 8.514 jiwa dengan mayoritas penduduk bekerja di sektor informal. Walaupun terdapat banyak keluarga miskin, namun warga di wilayah tersebut memiliki kewajiban untuk kerja bakti lingkungan dan membersihkan Sungai Cikapundung. Kondisi tersebut menunjukkan masih ada warga masyarakat yang peduli terhadap kebersihan Sungai Cikapundung (Bambang Rustanto, diakses tanggal 29 Juni 2013)

\section{Karakteristik Komunitas}

Komunitas Kelurahan Cipaganti, terdiri darilima komunitas yang masih aktif yaitu komunitas Bagasi, Geteke02, Bugasil, Gtek, dan Kowaci 04. Komunitas tersebut masih aktif dalam melakukan kegiatan kebersihan di sungai Cikapundung. Komunitas ini didirikan dari adanya diskusi mengenai keprihatinan tentang kondisi sungai Cikapundung yang semakin kotor dan dipenuhi oleh sampah, serta adanya anjuran dari 
pemerintah untuk melakukan gerakan kepedulian terhadap sungai Cikapundung.

Komunitas Kelurahan Lebak Siliwangi, terdiri dari tiga komunitas yaitu komunitas Katak, Zero, dan Bank Sampah. Komunitas tersebut ada yang aktif dan adajuga yang tidak aktif. Hal ini terjadi karena sebagian besar komunitas dibentuk setelah ada program dari pemerintah untuk melakukan "Gerakan Cikapundung Bersih". Namun terjadinya pergantian kepemimpinan di Kota Bandung, Gerakan Cikapundung Bersih tersebut terhenti, diikuti dengan tidak aktifnya beberapa komunitas masyarakat yang ada di Kelurahan Babakan Siliwangi. Komunitas yang masih aktif saat ini adalah komunitas Bank Sampah. Komunitas tersebut sampai saat ini masih mengolah sampah menjadi barang yang bernilai ekonomi.

Komunitas Kelurahan Tamansari, terdiri dari sepuluh komunitas yang masih aktif, dengan jumlah anggota yang cukup banyak, yaitu Kuya 13, BCA (Barudak Cikapundung Asli), ANPIC 16, Ikan Mas RW 02, CURUG 007, Kuya Orbit 10, ANJK 16, INDUNG, Buyur Cikapingkal, Kuya Gaya. Aktifitas yang dilakukan komunitas adalah kegiatan membersihkan Cikapundung (setiap hari Sabtu), melakukan sosialisasi dan pelatihan pengelolaan sampah baik secara mandiri maupun melibatkan organisasi non pemerintah pecinta lingkungan. Kegiatan lain yaitu melakukan edukasi, melakukan ajakan dan himbauan pada seluruh masyarakat di bantaran sungai Cikapundung, serta melakukan aktivitas lainnya yang memungkinkan dapat mengubah kebiasaan masyarakat seperti melakukan lomba memancing ikan, sebagai upaya untuk menjaga kebersihan sungai. Tujuan dibentuknya komunitasyaitu untuk menjalin silaturahmi antar sesama komunitas yang berada di bantaran sungai Cikapundung, menciptakan masyarakat yang sehat, bersih, hijau dan berjiwa sosial, mendidik masyarakat untuk berperilaku hidup bersih, menghidupkan kembali kegiatan gotong royong serta kebersamaan antar sesama masyarakat yang tinggal di bantaran Sungai Cikapundung.

Komunitas Kelurahan Babakan Ciamis, terdiri dari empat komunitas yaitu Kecebong Anyut, Sekoci, BKC, dan Komunitas PKK OPSIH. Komunitas ini dibentuk untuk mempererat silaturahmi antar warga, memiliki kepedulian yang sama terhadap sungai Cikapundung, dan adanya kebutuhan masyarakat terhadap lingkungan yang bersih dan sehat. Komunitas ini dibentuk dengan tujuan : (1) sebagai sarana edukasi dan penyuluhan bagi masyarakat terutama mengenai kebersihan sungai Cikapundung;(2) sebagai sarana pemberdayaan bagi masyarakat sekitar 
sungai Cikapundung; (3) sebagai upaya untuk menjaga kebersihan lingkungan sungai.

Komunitas Kelurahan Braga, terdiri dari komunitas KWAPLI, MAWAR, dan komunitas ABRAG PEDUNG (Anak Braga Peduli Cikapundung). Tujuan didirikannya komunitas yaitu untuk membangun kesadaran dan kebersamaan menjaga kebersihan kawasan sungai Cikapundung. Sebagian besar komunitas yang ada di Kelurahan Braga sudah tidak aktif lagi, karena tidak adanya program rutin yang dilakukan oleh komunitas untuk menjaga agar anggota komunitas tetap memiliki aktivitas yang berarti.

\section{Gerakan Komunitas dalam Pengelolaan Sampah}

Gerakan sosial dalam pengelolaan sampah yang ada di sepanjang bantaran Sungai Cikapundung, bergulir dari adanya kesadaran masalah bersama, yakni lingkungan yang bersih.Munculnya kesadaran tersebut karena adanya peran tokoh berpengaruh yang mampu menggerakkan masyarakat di beberapa kelurahan yang ada di bantaran sungai Cikapundung. Peran tokoh masyarakat yang mampu menggerakkan masyarakat tersebut menjadi penting, karena selain memiliki kemampuan untuk mengajak masyarakat, juga dapat menggerakkan masyarakat tidak hanya di satu komunitas dan satu kelurahan saja, akan tetapi mampu menjadi gerakan sosial yang muncul di kelurahan-kelurahan yang dilalui oleh sungai Cikapundung.

Gerakan yang dibangun ini juga tidak saja mampu menggerakkan masyarakat yang bersentuhan langsung dengan wilayah sungai Cikapundung, tetapi juga mampu menjadi daya tarik bagi komunitas masyarakat yang tidak berhubungan langsung dengan sungai Cikapundung, seperti kelompok mahasiswa yang secara sukarela mau terlibat melakukan kegiatan kebersihan sungai Cikapundung.Berdasarkan hasil wawancara, gerakan sosial telah berkembang menjadi gerakan sosial yang terbuka. Akan tetapi sejatinya gerakan sosial tersebut diawali dengan adanya keinginan pemerintah untuk melihat sungai cikpapundung menjadi bersih kembali.

Gerakan sosial dalam pengelolaan sampah ini jika dikaji dari teori partisipatif Paulo Freire dapat diartikan sebagai suatu proses pembelajaran masyarakat, di mana pembelajaran tersebut dilakukan untuk mengatasi masalah dan meningkatkan kualitashidup masyarakat tersebut. Hal ini dinilai tepat untuk mengajak masyarakat berpartisipasi 
dalam upaya perubahan didalam masyarakat itu sendiri, terutama dalam menjaga lingkungan sungai Cikapundung.

\section{Pola Pengorganisasian Masyarakat dalam Pengelolaan Sampah}

Setiap komunitas memililki dasar pertimbangan yang berbedabeda dalam melakukan peroganisasian masyarakat. Di Kelurahan Cipaganti, berorientasi pada tujuan sosial yang lebih besar. Program komunitas ini lebih dapat bertahan, karena didasari oleh suatu landasan berupa kesepakatan bersama bahwa menjaga lingkungan adalah kewajiban semua anggota masyarakat. Nilai gotong royong masih dipertahankan di wilayah ini untuk menjaga kebersihan lingkungan sungai.

Berbeda dengan Keluruhan Cipaganti, Kelurahan Lebak Siliwangi didasari dengan adanya harapan bahwa komunitas masyarakat akan lebih siap dalam menghadapi permasalahan lingkungan melalui pembentukan kelembagaan. Dengan adanya komunitas, distribusi tugas dan tanggun jawab menjadi lebih mudah dan memudahkan komunikasi dengan komunitas yang lain. Selain itu, melalui komunitas, segala aktivitas menjadi terukur dan dapat dipertanggung jawabkan.

Selanjutnya di Kelurahan Tamansari, kegiatan pengorganisasian masyarakat ditujukan untuk : (1) meningkatkan gotong royong; (2) meningkatkan kepedulian masyarakat terhadap kebersihan lingkungan sungai;(3) memudahkan komunikasi dengan pihak luar baik pemerintah ataupun swasta yang memiliki kepedulian yang sama; (4) meningkatkan nilai kebersamaan (sabilulungan), dan (5) untuk mengembangkan rasa kekeluargaan.

Sementara itu di Kelurahan Babakan Ciamis dan kelurahan Braga, yang melandasi komunitas dalam melakukan pengorganisasian yaitu : (1) kegiatan pemberdayaan pada warga masyarakat; (2) membangkitkan nilai gotong royong antar sesama warga; (3) meningkatkan nilai kebersamaan, saling percaya dan saling menghargai.

Landasan komunitas dalam melakukan pengorganisasi tersebut sangat berguna karena memiliki nilai kesukarelaan, tanpa pamrih, kesungguhan dan nilai-nilai lainnya yang menjadi landasan bagi komunitas dalam melakukan kegiatan kebersihan sungai Cikapundung. Nilai-nilai tersebut tumbuh, karena persoalan sampah yang ada di sungai Cikapundung berawal dari tidak adanya kesadaran sebagian masyarakat tentang kebersihan lingkungan, khususnya sungai. Dengan adanya gerakan komunitas pada masyarakat yang tinggal di bantaran sungai 
Cikapundung, diharapkan dapat memberikan dampak sosial yang luas tidak saja bagi komunitas yang tinggal di bantaran Sungai Cikapundung wilayah hilir, tetapi juga menggugah kesadaran masyarakat yang tinggal di hulu sungai Cikapundung untuk tidak membuang sampah ke sungai.

Gerakan sosial sesungguhnya bukanlah sebuah konsep baru dalam pergerakan perubahan sosial di Indonesia. Konsep ini semakin menguat tatkala issue civil society semakin mengemuka pasca reformasi tahun 1998. Fakih (2003) menganjurkan bahwa gerakan sosial merupakan suatu alternatif yang dapat dipilih oleh suatu kelompok non-partisan atau organisiasi non politik dalam hal praksis terhadap penguatan masyarakat sipil. Melalui gerakan sosial, keterlibatan anggota-anggota komunitas pada hakikatnya menjadikan manusia sebagai subyek aktif dalam tindakan-tindakan sosial.

Merujuk pada Suharko (2006) tidak ada definisi tunggal dalam konsep gerakan sosial. Giddens (1993; dalam Suharko, 2006: 3) menyatakan bahwa gerakan sosial merupakan upaya kolektif untuk mengejar kepentingan bersama. Selanjutnya Tarrow (1998; dalam Suharko: 2006: 3) menyatakan bahwa gerakan sosial merupakan tantangan-tantangan kolektif yang didasarkan pada kepentingan bersama. Dari dua definisi tersebut, gerakan sosial tersebut merupakan gerakan yang bersifat menentang untuk mencapai tujuan bersama (Suharko, 2006:3). Sifat menentang di sini dimaksudkan sebagai upaya melawan suatu hal yang telah biasa dilakukan dan menjadi habitus yang umum dilakukan oleh masyarakat. Oleh karenanya gerakan sosial merupakan sebuah tindakan yang menggejala sebagai upaya mengubah kondisi atau perbaikan kondisi pada suatu masyarakat.

Mengacu pada Tarrow (1998: 4-7; dalam Suharko, 2006: 5), suatu gerakan sosial memiliki empat properti dasar, yakni 1) tantangan kolektif; 2) tujuan bersama; 3) solidaritas kolektif; 4) memelihara politik perlawanan. Dalam terminologi politik perlawanan, hal tersebut dimaksudkan sebagai upaya melawan tindakan-tindakan yang tidak dikehendaki oleh kelompok organisasi non politik/komunitas dalam rangka mengubah atau memperbaiki kondisi hidup kelompok tersebut.

Partisipasi komunitas dan anggota komunitas menjadi hal terpenting dalam praksis gerakan sosial dalam komunitas. Gagasan ini bermuara pada konsep gerakan komunitas partisipatif yang digagas oleh Freire (dalam Wicaksono et al., 2001 : 6). Freire, pada tataran tertentu senada dengan Tarrow (1998), bahwa gerakan komunitas dimulai dari proses pengenalan masalah bersama, pengenalan kebutuhan potensi dan 
sumber daya, penggalangan potensi dan sumber daya, dan melakukan aksi penyelesaian masalah. Pembedaan yang terdapat dari propertiproperti tersebut adalah gagasan Freire lebih bersifat moderat daripada empat properti yang digagas oleh Tarrow.

Gerakan komunitas yang ada di Bantaran Sungai Cikapundung pada dasarnya sama, yakni sebagai gerakan yang menginginkan perubahan dan perbaikan akan lingkungan di bantaran dan sungai Cikapundung. Utami (2008:65) menjelaskan bahwa komunitas yang didampingi oleh pendamping lokal yang berbasis industri cenderung lebih aktif dibandingkan gerakan komunitas yang menekankan efisiensi ekologis. Gerakan komunitas yang menjadi fokus kajian ini secara umum merupakan gerakan komunitas yang didampingi pendamping atau motivator lokal, tetapi lebih menekankan pada keinginan untuk perubahan dan perbaikan lingkungan, sehingga terjadi perubahan yang bermanfaat pada aspek sosial, budaya, dan kelembagaan yang ada.

Mengacu pada model partisipasi Paolo Freire (dalam Wicaksono, A. Wazir dan Taryono Darusman, 2001 : 6), gerakan komunitas dimulai dari proses pengenalan masalah bersama, pengenalan kebutuhan potensi dan sumber daya, penggalangan potensi dan sumber daya dan melakukan aksi penyelesaian masalah. Alur praksis model strategi Paolo Freire adalah sebagai berikut :

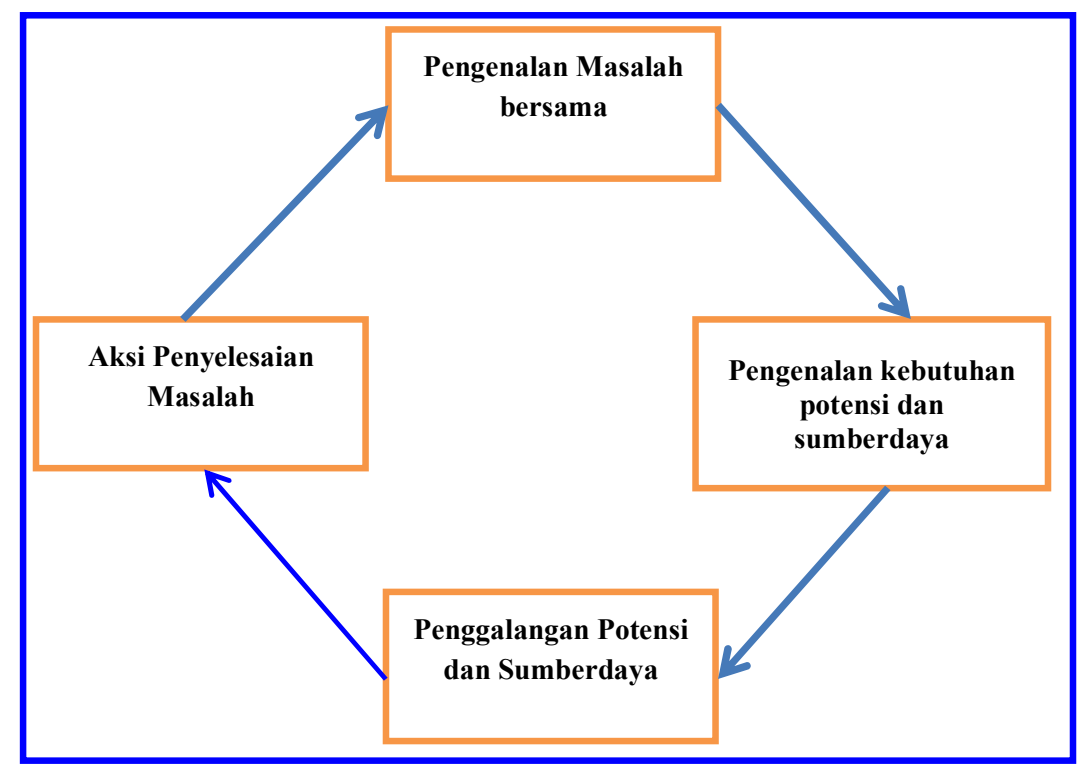

Merujuk pada model strategi Paolo Freire di atas, gerakan komunitas di bantaran sungai Cikapundung menunjukkan tiga pola 
pengorganisasian yang berbeda. Pertama, gerakan komunitas yang pola pengorganisasiannya berasal dari masyarakat sendiri (internal). Komunitas yang terbentuk tersebut berasal dari kesadaran internal masyarakat. Kedua, komunitas yang terbentuk karena pengaruh dari luar komunitas (eksternal). Komunitas tersebut terbentuk karena mendapatkan pengaruh dari komunitas lain yang sudah terbentuk lebih dahulu. Komunitas yang memperoleh pengaruh dari luar tersebut dicirikan dengan usia komunitas yang masih muda, program kerja yang tidak jelas, dan lebih banyak mengikuti kegiatan yang telah ada sebelumnya.Ketiga, komunitas yang terbentuk karena anjuran atau instruksi dari luar komunitas, seperti dari pihak pemerintah atau adanya tokoh masyarakat yang berpengaruh dan memiliki kekuatan untuk menggerakan masyarakat untuk melakukan gerakan sosial, seperti "Gerakan Cikapundung Bersih".

Dikaji dari proses terbentuknya komunitas dan perkembangannya yang sangat cepat, gerakan komunitas yang berkembang di bantaran Sungai Cikapundung tersebut sangat fungsional, karena telah memberikan dampak terhadap meningkatnya partisipasi masyarakat dalam Program Cikapundung Bersih. Dapat dikatakan bahwa gerakan komunitas tersebut fungsional, karena pengolahan sampah yang dilakukan oleh masyarakat di bantaran sungai Cikapundung dilakukan melalui pembentukan organisasi komunitas. Selain itu dilakukan upaya untuk mengenali permasalahan sampah secara bersama-sama, mengenali kebutuhan potensi dan sumberdaya, penggalangan potensi dan sumberdaya, dan aksi penyelesaian bersama.

Komunitas yang ada di bantaran Sungai Cikapundung secara umum masih aktif, namun kegiatannya terbatas pada pembersihan sungai dan melakukan kegiatan sosial dan budaya di sekitar sungai Cikapundung.Komunitas tersebut tumbuh berdasarkan kepedulian terhadap keberadaan sungai, bahwa sungai adalah bagian dari hidupnya, sedangkan komunitas yang tumbuh karena pengaruh komunitas lain atau adanya dukungan materi atau dukungan lainnya, aktif dalam kelembagaan namun pasif dalam kegiatannya. Pasifnya kegiatan komunitas dikarenakan ketidakadaan dana dan fasilitas yang mendukung kegiatan komunitas tersebut. Merujuk pada pendapat Yogiesty et.al (2010:1) bahwa partisipasi masyarakat dalam suatu gerakan sangat tergantung pada persepsi masyarakat. Jika persepsi masyarakat mengatasi sampah adalah urusan pemerintah maka partisipasi dalam suatu gerakan akan rendah.Hasil penelitian menunjukkan bahwa gerakan komunitas 
yang tergantung pada pihak eksternal (pemerintah), kelembagaannya masih aktif namun kegiatan pasif. Hal ini berbeda dengan komunitas yang berangkat dari kebutuhan dan kesamaan pandangan, baik kelembagaan maupun kegiatannya aktif.

\section{SIMPULAN}

Gerakan komunitas yang berkembang di bantaran Sungai Cikapundung bersifat fungsional, karena telah memberikan dampak terhadap meningkatnya partisipasi masyarakat dalam Program Cikapundung Bersih. Gerakan komunitas tersebut terbentuk kedalam tiga pola gerakan. Pertama, gerakan yang terbentuk karena kesadaran internal dari dalam kelompok masyarakat itu sendiri. Gerakan ini umumnya mampu bertahan dan aktif dalam waktu yang lama, karena motivasi dan kepedulian masyarakat pada sungai Cikapundung terbangun dari dalam komunitas itu sendiri. Kedua, komunitas yang gerakannya terbentuk karena mendapatkan pengaruh dari luar komunitas itu sendiri, yaitu komunitas yang terbentuk karena pengaruh dari komunitas yang lain. Komunitas ini cenderung dapat bertahan karena telah melihat contoh dan pola serta manfaat dari gerakan yang dibangun oleh komunitas yang tumbuh karena kesadaran internal. Ketiga, komunitas yang terbentuk karena mendapatkan dorongan eksternal berupa motivasi atau dukungan dari pemerintah atau organisasi non pemerintah. Komunitas semacam ini biasanya bersifat temporer karena akan bergerak jika mendapat dukungan baik pendanaan ataupun dukungan lainnya.

Pola pengorganisasian komunitas yang tumbuh karena kesadaran internal (tipe pertama) merupakan komunitas yang cocok dengan model pola pengorganisasi partisipatif model PaoloFreire, karena komunitas tersebut terbentuk setelah adanya pengenalan masalah bersama, kemudian dilakukan upaya untuk mengenali kebutuhan potensi dan sumberdaya untuk menjadi suatu proses penggalangan potensi dan sumberdaya, yang akhirnya berkembang menuju suatu aksi penyelesaian masalah.Sementara itu, tipe komunitas kedua dan ketiga sulit untuk bertahan karena selalu tergantung pada bantuan dari luar komunitas.

\section{DAFTAR PUSTAKA}

\section{Buku}

Beckwith, D., \& Lopez, C. (1997). Community organizing: People power from the grassroots. Washington, DC: Center for Community Change. 
Creswell, J. W. 1998. Qualitative Inquiry And Research Design Choosing Among Five Traditions. Thousand Oaks, California: Sage.

Direktur Jenderal Kelautan, Pesisir, dan Pulau-Pulau Kecil. 2006.Panduan pembelajaran mandiri pengorganisasian masyarakat. Jakarta.[02/03/13]

Gurici, Imran. 2012. Perencanaan pengelolaan sampah dengan Pendekatan partisipatif. Jakarta:Universitas Indonesia.

Herdiansyah, Haris. 2010. Metodologi Penelitian Kualitatif Untuk Ilmu-Ilmu Sosial. Jakarta : Salemba Humanika.

Locher, David A. 2002. Collective. Parson zeducation Inc. Upper Saddle River : New Jersey.

Moleong, Lexy J. 2006. Metodelogi Penelitian Kualitatif. Ramaja Rosda Karya : Bandung.

Ritezer, George. 2007. Sosiologi Ilmu Pengetahuan Berparadigna Ganda. Jakarta : Rajawali Perss.

Ritzer, George dan Douglas Goodman J. 2004. Teori Sosiologi Modern. Jakarta : Kencana.

Ritzer, George. 2002. Sosiologi Ilmu Pengetahuan Berparadigma Ganda. Raja Grafindo Persada : Jakarta.

Ritzer, George, Goodman Douglas J. 2003. Teri Sosiologi Modern. Kencana : Jakarta.

Suryabrata, Sumadi. 1983. Metodologi Penelitian. Jakarta:Rajawali Persada

Tarrow, Sidney. 1994. Power in Movement:Social Movement, Collective Actions, and Politics.Cambridge : Cambridge University Press.

Wicaksono, A. Wazir dan Taryono Darusman. 2001. Pengalaman Belajar Praktek Pengorganisasian Masyarakat Di Simpul Belajar. Bogor: Simpul Belajar Pengorganisasian Masyarakat Yayasan Puter.

\section{Jurnal}

Suharko. 2006. Gerakan Sosial Baru di Indonesia: Repertoar: Gerakan Petani. Jurnal Ilmu Sosial dan Ilmu Politik. Vol. 10 No 1. Juli 2006

Utami, Beta Dwi. (Tanpa tahun). Pengelolaan Sampah Rumah Tangga Bebrbasis Komunitas: Teladan dari Dua Komunitas di Sleman dan Jakarta Selatan. Sodality : Jurnal Transdisiplin Sosiologi, Komunikasi dan Ekologi Manusia, April 2008. P49-68.

Viradin Yogiesti, Setiana Hariyani, Fauzul Rizal Sutikno.(Tanpa Tahun). Pengelolaan Sampah Terpadu Berbasis Masyarakat kota kediri. Jurusan Perencanaan Wilayah dan Kota Fakultas Teknik Universitas Brawijaya. JurnalTata Kota dan DaerahVolume 2, Nomor 2, Desember 2010.

\section{Laporan Penelitian}

Gunawan, Wahyu, et.al. 2012. Gerakan Komunitas Kota Dalam Upaya Memperbaiki Kualitas Lingkungan di Kota Bandung. Bandung. 
Sekarningrum, Bintarsih, et al. 2013. Perilaku Masyarakat dalam Membuang Sampah di Bantaran ungai Cikapundung Kota Bandung. Bandung.

\section{Elektronik}

Bambang Rustanto.2010. Kemiskinan di Kelurahan Babakan Ciamis. http:// bambang-rustanto.blogspot.com/2010/03/kemiskinan-dibabakan-ciamis-bandung.html. diakses tanggal 29 Juni 2013)

Tamrin, Muhamad. 2011. Efektifitas Pengelolaan Sampah dalam Menciptakan Kebersihan Lingkungan Di Kota Medan.<http://repository.usu.ac.id>

Universitas Komputer Indonesia. 2012. http://www.pdfe8dc.org.

\section{Dokumen}

Kecamatan Coblong. 2012. Profil dan Tipologi Kecamatan Coblong. Bandung.

Kecamatan Bandung Wetan. 2012. Profil dan Tipologi Kecamatan Bandung Wetan. Bandung.

Kecamatan Sumur Bandung. 2012. Profil dan Tipologi Kecamatan Sumur Bandung. Bandung.

Kelurahan Cipaganti. 2013. Profil dan Tipologi Kelurahan Cipaganti. Bandung.

Kelurahan Cipaganti. 2013. Monografi Kelurahan Cipaganti. Bandung.

Kelurahan Lebak Siliwangi. 2014. Profil dan Tipologi Kelurahan Lebak Siliwangi. Bandung

Kelurahan Tamansari. 2012. Profil dan Tipologi Kelurahan Tamansari. Bandung.

Kelurahan Tamansari. 2013. Monografi Kelurahan Tamansari. Bandung.

Kelurahan Babakan Ciamis. 2014. Profil dan Tipologi Kelurahan Babakan Ciamis. Bandung.

Kelurahan Babakan Ciamis. 2012. Monografi. Bandung.

Kelurahan Braga. 2014. Profil dan Tipologi Kelurahan Braga. Bandung.

Kumpulan Undang-Undang; Sumber Daya Air, Pengelolaan Sampah, Penanggulangan Bencana, Perlindungan dan Pengelolaan Lingkungan Hidup. 2011. Kapal Jawa Timur. 